\title{
The Effect of Blood Transfusion on Outcomes in Aortic Surgery
}

\author{
Camilo A. Velasquez, MD ${ }^{1}$ Mrinal Singh, MB, BChir ${ }^{1}$ Syed Usman Bin Mahmood, MBBS ${ }^{1}$ \\ Adam J. Brownstein, BA ${ }^{1}$ Mohammad A. Zafar, MBBS ${ }^{1}$ Ayman Saeyeldin, MD ${ }^{1}$ \\ Bulat A. Ziganshin, MD, $\mathrm{PhD}^{1,2}$ John A. Elefteriades, $\mathrm{MD}^{1}$
}

${ }^{1}$ Aortic Institute at Yale-New Haven Hospital, Yale University School of Medicine, New Haven, Connecticut

2 Department of Surgical Diseases \#2, Kazan State Medical University, Kazan, Russia

Address for correspondence John A. Elefteriades, MD, Aortic Institute at Yale-New Haven Hospital, Yale University School of Medicine, Clinic Building CB 317, 789 Howard Avenue, New Haven, CT 06510 (e-mail: john.elefteriades@yale.edu).

Int J Angiol 2017;26:135-142.

\author{
Abstract \\ Keywords \\ - cardiac surgical \\ procedures \\ - thoracic surgery \\ - thoracic aorta \\ - blood transfusion \\ - morbidity \\ - mortality \\ - thoracic aortic \\ aneurysm \\ - dissection
}

The use of blood transfusion in cardiac surgery varies widely. The beneficial effects of blood products are offset by an increase in morbidity and mortality. Despite multiple studies showing an association between blood product exposure and adverse shortand long-term events, it is difficult to determine causality. Nevertheless, the implication is sufficient to warrant the search for alternative strategies to reduce the use of blood products while providing a standard of care that optimizes postoperative outcomes. Aortic surgery, in particular, is associated with an increased risk of bleeding requiring a blood transfusion. There is a paucity of evidence within aortic surgery regarding the deleterious effects of blood products. Here, we review the current evidence regarding patient outcomes after blood transfusion in cardiac surgery, with special emphasis on aortic surgery.
Blood transfusion is the most common form of transplantation in current practice. Worldwide, 75 million units of blood are donated every year. Of these, 24 million units are transfused in the United States reflecting a high economic and health care burden. ${ }^{1-3}$ In cardiac surgery, $50 \%$ of patients receive transfusions, and up to a fifth of these patients utilize the majority of blood products intraoperatively. ${ }^{2}$ This translates to $20 \%$ of the available U.S. supply. ${ }^{4}$

Notwithstanding its well-known complications, there is increasing evidence suggesting that blood transfusion is associated with an increase in morbidity and mortality, in both the short and long term. However, the evidence is conflicting, and transfusion policies in cardiac surgery vary widely. This absence of consensus is even greater in aortic surgery, where research does not adequately address the issue of outcomes. ${ }^{4-6}$ Transfusion policies are often extrapolated from studies examining other cardiac procedures (e.g., coronary artery bypass grafting [CABG], valve replacement). Here, we briefly summarize the benefits and risks of blood transfusion before reviewing current practices in cardiac surgery. We focus on the effects of perioperative transfusion on outcomes, with an emphasis on the management of patients undergoing aortic procedures.

\section{Benefits and Risks of Blood Transfusion}

The role of blood transfusion (specifically, packed red blood cells-PRBC) is twofold: oxygen transport and volume expansion. Since intravascular volume can be expanded effectively using crystalloids and other colloids, the primary function of PRBC transfusion is the increase in oxygencarrying capacity of the circulation to provide sufficient oxygen to meet the metabolic demands of body tissues. ${ }^{7}$ In trauma, hemorrhage results in ischemia and metabolic 
acidosis due to anaerobic metabolism. Blood transfusion is required to reverse this derangement. Severely anemic patients also exhibit organ dysfunction due to the reduced oxygen-carrying capacity. ${ }^{8,9}$ Therefore, the true benefits of transfusion are limited to these specific indications.

Despite its beneficial effects, blood transfusion is not without harm. Adverse effects are well documented and include acute and chronic hemolytic reactions, nonimmune hemolysis, anaphylaxis, transfusion-related acute lung injury, graft versus host disease, circulatory overload, and infectious disease transmission. ${ }^{1}$

Immunomodulatory effects influence short- and longterm outcomes. Outcomes are affected by duration of storage, as well as leukocyte level in the PRBC units. Blood products stored for longer than 14 days are associated with an increased risk of prolonged intubation, renal failure, sepsis, multiorgan failure, and in-hospital death, together with a reduction in survival during the first 6 months. The mechanism is not completely understood but might be related to the development of a "storage lesion" decreasing the availability of oxygen delivery, impeding microvascular flow, and increasing systemic inflammation. ${ }^{10}$ Moreover, white blood cells contribute to transfusion-related immunomodulation. Nonleukoreduced blood activates the host immune system, changing the immune modulatory profile. There is a decrease in circulating lymphocytes, modification of the T-cell helper/suppressor ratio, and downregulation of the antigen-presenting cell. These changes make patients increasingly vulnerable to external insults. ${ }^{11}$

\section{Blood Transfusion in Cardiac Surgery}

Cardiac surgical procedures are associated with an increased risk of bleeding. ${ }^{12}$ The extent of blood utilization varies widely across institutions, ranging from 3 to $92 \%$ of patients. $^{12}$ The proportion receiving only one unit of PRBC is 22 to $67 \%$, while 5 to $25 \%$ of patients received greater than five units, independent of hospital characteristics. ${ }^{3}$

Blood products are used to treat coagulopathies and anemia, thereby limiting bleeding and augmenting oxygen-carrying capacity. ${ }^{2}$ Multiple intrinsic and extrinsic factors contribute to the need for blood transfusion. These factors are patient-related and procedure-related. Some patient factors include coagulopathy and platelet disorders, while procedure-related factors include hypothermia and qualitative platelet defects secondary to cardiopulmonary bypass (CPB). ${ }^{2}$

Many studies have shown an association between transfusion and increases in short- and long-term mortality, resulting in a shift from the liberal use of blood to a more restrictive and goal-directed strategy. The aims are more efficient blood utilization and reduction in the rate of transfusion-related complications, with an expected improvement in outcomes and long-term quality of life. ${ }^{2,12,13}$ Koch et al $^{14}$ identified a biphasic pattern of mortality after CABG, with an early peak at 6 months, and a later peak at about 10 years after surgery in those who were transfused. The risk-adjusted reduction in survival was $0.34 \pm 2(p<0.0001)$ for the early phase, and
$0.074 \pm 0.016(p<0.0001)$ for the late phase. This study and corroborating research highlighted the deleterious effects of a liberal transfusion policy. They likened the liberal use of blood transfusion to arbitrary antibiotic administration to every patient with fever, stressing that blood transfusion has specific indications and should not be used indiscriminately. ${ }^{12} \mathrm{Yu}$ et $\mathrm{al}^{15}$ observed an incremental increase in the rate of postoperative complications with each additional unit of PRBC transfused $(0,0.35,2.29 \%$ for septicemia; $0,0.7$, and $2.29 \%$ for pneumonia, for one, two, and three units, respectively). The intubation time was also prolonged from 11 hours with one unit to 13 hours with three units. Their demonstration of the cumulative adverse effects of blood transfusion suggested the benefit of reducing transfusion volume. Surgenor et $\mathrm{al}^{16}$ showed, after adjusting for variables, that a lower intraoperative nadir hematocrit was associated with developing lowoutput heart failure (odds ratio [OR], 1.27; 95\% confidence interval $[\mathrm{CI}], 1-1.61 ; p=0.047)$. Furthermore, Koch et al identified perioperative blood transfusion as the single most reliable factor associated with postoperative morbidity. ${ }^{17}$ They described an increase in mortality (OR, 1.77; 95\% CI, 1.67-1.87; $p<0.0001$ ), renal failure (OR, 2.06; 95\% CI, 1.87-2.27; $p<0.0001$ ), prolonged ventilator support (OR, 1.79; $95 \% \mathrm{CI}$, $1.72-1.86 ; p<0.0001$ ), severe infection (OR, 1.76; 95\% CI, 1.47-1.63; $p<0.0001$ ), cardiac complications (OR, 1.76; 95\% CI, 1.47-1.63; $p<0.0001$ ), and neurologic events (OR, 1.37; 95\% CI, 1.30-1.44; $p<0.0001$ ).

Importantly, the retrospective nature of these observational studies makes it difficult to assess the exact relationship between blood transfusion and adverse events. The association may be influenced by numerous confounders that might not be accounted for during the statistical analysis. ${ }^{14-17}$ One potential confounder that may impact outcomes is the severity of clinical presentation. Inherently high-risk patients, such as those with multiple comorbidities, complex clinical presentations, and emergent operations, naturally tend to have lower survival. Nevertheless, even in studies that evaluate nonhighrisk patients, the outcomes are still conflicting. For instance, while Paone et al showed an increased morbidity and mortality after on-pump CABG with as little as one or two units of PRBC, Koster et al did not show an increase in mortality or adverse perioperative outcomes in patients receiving equal amount of blood products. ${ }^{18,19}$

Some centers give blood transfusions to patients with stable cardiovascular disease in anticipation of intraoperative hemorrhage. Paone et $\mathrm{al}^{18}$ described the routine use of one to two units of PRBC, and showed an association with increased mortality after propensity adjustment (OR, 1.86; 95\% CI, $1.21-2.87 ; p=0.005$ ). Murphy et $\mathrm{al}^{20}$ analyzed the effect of giving increasing volumes of blood, comparing outcomes with patients who did not receive transfusions. Patients receiving only one unit of PRBC had a $63 \%$ increase in ischemic complications and a $46 \%$ increase in infectious complications, while those exposed to two units had an increase of $130 \%$ and $136 \%$, respectively. Moreover, they demonstrated an $11 \%$ and $21 \%$ increase in transfusion cost with one and two units, respectively. They showed not only the adverse association with increasing quantities of blood transfusion but also its existence 
even with low blood product use, highlighting the harmful effect of this practice. ${ }^{18}$

\section{Age}

Age is another factor that influences outcomes, and elderly patients invariably have more comorbidities than their younger counterparts. Cardiac surgery is increasingly performed in older patients. Preoperative anemia is common in this population, with a prevalence of one in eight patients older than 65 years; ${ }^{21}$ and this is reflected in their greater use of blood products. ${ }^{22}$ In spite of this, studies have not shown a statistically significant association between transfusion and adverse events in these patients. Yun et $\mathrm{al}^{22}$ found no association between early and late mortality with the use of one to two PRBC units in octogenarians (early mortality hazard ratio [HR], 1.47; 95\% CI, 0.84-2.56; $p>0.05$ and late mortality HR, 0.92; 95\% CI, 0.50-1.69; $p>0.05$ ). Meanwhile, Carrascal et $\mathrm{al}^{23}$ did not report a significant change in early or late survival with the use of one to two units of PRBC. However, transfusion may be of benefit in the elderly. Although not in the context of cardiac surgery, Wu et $\mathrm{al}^{24}$ demonstrated an improvement in 30-day mortality in patients undergoing transfusion who experienced an acute myocardial infarction with low hematocrit $(<24 \%)$.

\section{Confounders}

Many other variables influence outcomes and act as confounders in any observational study. Indeed, the surgery itself is a risk factor due to the systemic inflammatory response precipitated by the procedure and the use of CPB. ${ }^{12}$ Thus, the etiologic association of blood transfusion with mortality is difficult to establish in the complex cardiac surgical patient.

\section{Counterevidence}

Recent studies have challenged the negative association of transfusion in cardiac surgical patients. Koster et $\mathrm{al}^{19}$ did not find an increase in 30-day mortality in patients undergoing CABG exposed to one to two units of PRBC (OR, 0.29; 95\% CI, $0.06-1.50 ; p=0.14$ ). Apart from a prolonged intensive care unit (ICU) stay (longer than 48 hours), there was no statistical difference in any other major clinical complication such as stroke, the requirement of hemofiltration, low cardiac output, wound infections, and prolonged mechanical ventilation. Dardashti et $\mathrm{al}^{25}$ did not find an association between PRBC transfusion and reduced long-term survival after adjusting for hemoglobin $(\mathrm{Hg})$ and glomerular filtration rate in patients undergoing CABG. Although Warwick et $\mathrm{al}^{26}$ showed an increase in long-term mortality with the use of one unit of PRBC (by univariate analysis), they failed to show this relationship with Cox regression and propensity models. They identified preoperative anemia as a significant confounding factor $(p=0.02)$ but concluded that a single unit transfusion policy is safe. ${ }^{26}$

Differences in methodology, the retrospective and observational nature of the studies, and the lack of randomized trials likely underlie the heterogeneity of the results in the literature (-Tables 1 and 2). The ethical considerations and impracticality of a randomized clinical trial with a lifesaving procedure, such as blood transfusion, may jeopardize research in this area (-Table $\mathbf{1}$ ).

\section{Blood Transfusion in Aortic Surgery}

Within cardiac surgery, aortic surgery is considered an especially high-risk subspecialty, with many surgeries carrying a considerable risk of bleeding. Complex aortic reconstruction, urgent presentations, multiple suture lines, prolonged $\mathrm{CPB}$, and hypothermia account for the higher risk. ${ }^{6}$ Unsurprisingly, there is a greater likelihood of exposure to blood products. ${ }^{2,13}$ Nevertheless, most studies have excluded this group of patients from their analysis, and consequently, current transfusion guidelines are based on literature addressing nonaortic procedures. Current practices in aortic surgery are therefore not based on firm evidence.

The few studies that have addressed this issue have focused on comparisons between conventional (i.e., liberal transfusion) and conservative transfusion strategies, and as such can offer indirect insight into morbidity and mortality after blood product use. Smith et $\mathrm{al}^{5}$ demonstrated that patients receiving two or more units of PRBC were more likely to have suffered complications than those requiring zero to one unit $(p<0.001)$. Cambria et $\mathrm{al}^{27}$ found that PRBC transfusion was one of the independent risk factors for mortality in patients undergoing thoracoabdominal surgery (OR, 1.4; 95\% CI, 1.1-1.7; $p=0.005$ ). Chu et al, ${ }^{6}$ in their evaluation of transfusion practices, found that the patients in the blood conservation group did indeed have less blood transfused, and had lower morbidity than the control group. However, a difference in mortality was not seen. Argalious et $\mathrm{al}^{11}$ studied the effect of blood transfusion in patients undergoing endovascular aortic repair. Although they found an association with in-hospital morbidity and mortality in the univariate analysis (OR, 2.94; 95\% CI, 1.96-4.46; $p<0.001$ ), propensity matching, and multivariate analysis yielded no statistically significant association (OR, 2.7; 95\% CI, $0.8-9.0 ; p=0.11$ ). To the best of our knowledge, this is the only study in the field of aortic intervention that directly relates transfusion with outcomes. The endovascular nature of the procedure studied, with its presumably lesser proinflammatory stimulus, may account for the disparity in results compared with the majority of the cardiac surgery literature (-Table 2$)^{11}$

\section{Impact and Management of Perioperative Anemia}

Among cardiothoracic surgery patients, some variables have been found to correlate with the likelihood of receiving a transfusion. These include advanced age, low preoperative hemoglobin concentration, preoperative antiplatelet, and antithrombotic medication, complex cardiac procedures, and redo surgeries, emergency surgery, and noncardiac comorbidities. ${ }^{2,12}$ Among these, anemia is an independent risk factor associated with worse outcomes and has been 
Table 1 Summary of studies in cardiac surgery evaluating the effect of blood transfusion on morbidity and mortality

\begin{tabular}{|c|c|c|c|c|c|c|c|c|c|c|}
\hline \multirow[t]{3}{*}{ Study } & \multirow{3}{*}{$\begin{array}{l}\text { Number } \\
\text { of } \\
\text { patients }\end{array}$} & \multirow[t]{3}{*}{ Patient group } & \multicolumn{4}{|c|}{ Mortality } & \multicolumn{3}{|c|}{ Morbidity } & \multirow[t]{3}{*}{ Additional information } \\
\hline & & & \multicolumn{2}{|l|}{ Yes } & \multirow[t]{2}{*}{ No } & \multirow[t]{2}{*}{ N/A } & \multirow[t]{2}{*}{ Yes } & \multirow[t]{2}{*}{ No } & \multirow[t]{2}{*}{ N/A } & \\
\hline & & & Early & Late & & & & & & \\
\hline Koch et al ${ }^{14}$ & 10,289 & CABG & $\mathrm{x}$ & $x$ & & & & & $x$ & $\begin{array}{l}\text { Biphasic pattern of mortality: } 6 \text { mo } \\
\text { (early) and } 10 \text { y (late) }\end{array}$ \\
\hline Yun et $\mathrm{al}^{22}$ & 17,026 & $\begin{array}{l}\text { Octogenarians and CABG, } \\
\text { isolated valve, CABG + valve }\end{array}$ & & & $x$ & & & & $x$ & $\begin{array}{l}\text { Increased early death in } \\
\text { patients }<80 \mathrm{y}\end{array}$ \\
\hline Paone et al ${ }^{18}$ & 22,785 & CABG & $x$ & & & & $x$ & & & $\begin{array}{l}\text { Evaluation of the effect of } 1-2 \text { units of } \\
\text { PRBC }\end{array}$ \\
\hline Koster et a ${ }^{19}$ & 3,006 & CABG & & & $x$ & & & $x$ & & $\begin{array}{l}\text { Evaluation of the effect of } 1-2 \text { units of } \\
\text { PRBC }\end{array}$ \\
\hline Jakobsen et al ${ }^{43}$ & 20,001 & $\begin{array}{l}C A B G, \text { isolated valve, } \\
C A B G+\text { valve }\end{array}$ & $x$ & & & & & & $x$ & $\begin{array}{l}\text { Increased mortality in patients with } \\
\text { EUROSCORE } 0-4 \% \text { compared with } \\
\text { EUROSCORE }>5 \%\end{array}$ \\
\hline Murphy et al ${ }^{20}$ & 8,598 & $\begin{array}{l}\text { CABG, isolated valve, } \\
\text { CABG }+ \text { valve }\end{array}$ & $x$ & $x$ & & & $x$ & & & $\begin{array}{l}\text { Increased ICU and hospital LOS with } \\
\text { transfusion }\end{array}$ \\
\hline Surgenor et al ${ }^{16}$ & 3,254 & CABG & & & & $x$ & $x$ & & & $\begin{array}{l}\mathrm{PRBC} \text { and nadir hematocrit were } \\
\text { independently associated with LOHF }\end{array}$ \\
\hline Kleczynski et al ${ }^{44}$ & 101 & TAVR & & $x$ & & & & & $x$ & $\begin{array}{l}\text { Transfusion was associated with } \\
\text { increased LOS }\end{array}$ \\
\hline Surgenor et al ${ }^{45}$ & 9,079 & $\begin{array}{l}\text { CABG, isolated valve, } \\
\text { CABG+ valve }\end{array}$ & $x$ & & & & & & $x$ & N/A \\
\hline Engoren et $\mathrm{al}^{46}$ & 1,915 & CABG & & $x$ & & & & & $x$ & N/A \\
\hline Koch et al ${ }^{17}$ & 11,963 & CABG & $x$ & & & & $x$ & & & $\begin{array}{l}\text { Stepwise increment in risk for adverse } \\
\text { events with additional units of PRBC }\end{array}$ \\
\hline Santos et a ${ }^{47}$ & 3,004 & CABG & $x$ & $x$ & & & & & $x$ & $\begin{array}{l}\text { EUROSCORE }<2 \% \text { and patients }<60 \text { y } \\
\text { are associated with increased mortality }\end{array}$ \\
\hline $\mid s i l$ et $a^{21}$ & 288 & $\begin{array}{l}\text { CABG, isolated valve, } \\
\text { CABG }+ \text { valve }\end{array}$ & & & $x$ & & $x$ & & & $\begin{array}{l}\text { Transfusion was associated with renal } \\
\text { failure and thrombocytopenia }\end{array}$ \\
\hline Dardashti et al ${ }^{25}$ & 5,261 & CABG & & & $x$ & & & & $x$ & $\begin{array}{l}\text { GFR and } \mathrm{Hg} \text { are confounders for } \\
\text { decreased survival }\end{array}$ \\
\hline Warwick et $\mathrm{al}^{26}$ & 4,615 & CABG & & & $x$ & & & & $x$ & $\begin{array}{l}\text { Preoperative anemia is a confounder } \\
\text { for decreased survival }\end{array}$ \\
\hline Yu et al ${ }^{15}$ & 745 & $\begin{array}{l}\text { CABG and reoperation } \\
\text { with } \mathrm{CPB}\end{array}$ & & & & $x$ & $x$ & & & $\begin{array}{l}\text { Stepwise increase in postoperative } \\
\text { complications with additional PRBC } \\
\text { units }\end{array}$ \\
\hline Engoren et al ${ }^{48}$ & 940 & CABG & & & & $x$ & $x$ & & & $\begin{array}{l}\text { PRBC transfusion is associated with a } \\
20 \% \text { increase in graft occlusion }\end{array}$ \\
\hline
\end{tabular}

Abbreviations: $\mathrm{CABG}$, coronary artery bypass graft; CPB, cardiopulmonary bypass; GFR, glomerular filtration rate; Hg, hemoglobin; ICU, intensive care unit; LOHF, low-output heart failure; LOS, length of stay; N/A, not applicable; PRBC, packed red blood cells.

Table 2 Summary of studies in aortic surgery evaluating the effect of blood transfusion on morbidity and mortality

\begin{tabular}{|c|c|c|c|c|c|c|c|c|c|c|}
\hline \multirow[t]{3}{*}{ Study } & \multirow{3}{*}{$\begin{array}{l}\text { Number } \\
\text { of } \\
\text { patients }\end{array}$} & \multirow[t]{3}{*}{ Patient group } & \multicolumn{4}{|c|}{ Mortality } & \multicolumn{3}{|c|}{ Morbidity } & \multirow[t]{3}{*}{ Additional information } \\
\hline & & & \multicolumn{2}{|l|}{ Yes } & \multirow[t]{2}{*}{ No } & \multirow[t]{2}{*}{ N/A } & \multirow[t]{2}{*}{ Yes } & \multirow[t]{2}{*}{ No } & \multirow[t]{2}{*}{ N/A } & \\
\hline & & & Early & Late & & & & & & \\
\hline Yaffee et al ${ }^{4}$ & 132 & $\begin{array}{l}\text { Thoracic aortic aneurysm } \\
\text { and dissection }\end{array}$ & $x$ & & & & $x$ & & & Evaluation of the effectiveness of BCS \\
\hline Chu et $\mathrm{al}^{6}$ & 189 & $\begin{array}{l}\text { Ascending aortic and } \\
\text { arch surgeries }\end{array}$ & & & & $x$ & & & $x$ & Evaluation of the effectiveness of BCS \\
\hline Smith et $\mathrm{al}^{5}$ & 63 & $\begin{array}{l}\text { Aortic replacement } \\
\text { procedures }\end{array}$ & & & & $x$ & & & $x$ & Evaluation of the effectiveness of BCS \\
\hline Argalious et al ${ }^{11}$ & 510 & EVAR & & & $x$ & & & $x$ & & $\begin{array}{l}\text { Endografts: Abdominal aortic, } \\
\text { descending thoracic, and fenestrated }\end{array}$ \\
\hline Cambria et $\mathrm{al}^{27}$ & 337 & $\begin{array}{l}\text { Thoracoabdominal } \\
\text { aneurysm repair }\end{array}$ & $x$ & & & & $x$ & & & $\begin{array}{l}\text { Statistical significant association } \\
\text { with spinal cord ischemia }\end{array}$ \\
\hline
\end{tabular}

Abbreviations: BCS, blood conservation strategies; EVAR, endovascular aortic repair; N/A, not applicable. 
identified as a modifiable preoperative variable. Muñoz et $\mathrm{al}^{28}$ found that patients with uncorrected preoperative anemia (men $\mathrm{Hg}<13 \mathrm{~g} / \mathrm{dL}$, women $\mathrm{Hg}<12 \mathrm{mg} / \mathrm{dL}$ ) were more likely to receive transfusion and inotropic support postoperatively. They also had longer ICU stays than nonanemic patients. Hogervorst et $\mathrm{al}^{29}$ established a direct relationship between the degree of intraoperative anemia and adverse outcomes, with an increase in side effects as the degree of intraoperative anemia increased.

Consequently, judicious evaluation and treatment of preoperative anemia are required to avoid transfusion and improve postoperative outcomes. A patient's tolerance of blood loss is linked to the amount by which $\mathrm{Hg}$ decreases from preoperative baseline levels. Therefore, the lowest perioperative $\mathrm{Hg}$ level should not be the only guide that triggers transfusion. Rather, the percentage drop of $\mathrm{Hg}$ from baseline should play a major role in clinical decision-making. Karkouti et $\mathrm{al}^{30}$ described an increased risk of adverse events (hospital death, stroke, and acute kidney injury) with a greater than $50 \%$ decrease in the $\mathrm{Hg}$ concentration from preoperative baseline levels (adjusted OR, 1.53; 95\% CI, 1.12-2.08; $p=0.007$ ). This carries significant therapeutic implications when evaluating the need for transfusion, as patients with a relatively lower decrease from baseline Hg levels may compensate better for the anemic state than patients with larger declines from baseline values.

It is a common observation among aortic surgeons that anemia begets bleeding. That is, the blood needs to be "thick" enough to clot property. Many feel that a hematocrit greater than $30 \%$ is required for optimal coagulation.

\section{Transfusion Thresholds}

Transfusion thresholds provide guidance on when to transfuse the anemic patient. An appropriate threshold should balance the benefits of increased oxygen delivery with the risks of PRBC transfusion. A Cochrane review of clinical trials in noncardiac surgery and critical care ${ }^{31}$ found that transfusing at a lower level ( $\mathrm{Hg} 7-8 \mathrm{~g} / \mathrm{dL}$ ) compared with a higher level (Hg 9-10 g/dL) was associated with a $43 \%$ reduction in PRBC requirement (relative risk [RR], 0.57; 95\% CI, 0.49-0.65). There was no evidence that transfusing at this more restrictive level impacted 30-day mortality, development of cardiac events, stroke, pneumonia, thromboembolism, and infection (RR, $0.97 ; 95 \%$ CI, 0.81-1.16). Notably, cardiac patients with "active" disease were not studied. Thus, it is difficult to extrapolate the results above to cardiac surgical patients. Those with coronary artery disease (especially acute coronary syndromes) require higher $\mathrm{Hg}$ levels to maintain adequate oxygen delivery to the myocardial tissue. A fall in $\mathrm{Hg}$ increases the risk of ischemia with ensuing negative outcomes. ${ }^{32}$ For cardiac surgical patients, Murphy et $\mathrm{al}^{33}$ did not find a difference in the occurrence of severe infections, myocardial infarction, mesenteric infarction, or acute kidney injury between a liberal and restrictive strategy (33 vs. 35.1\%; OR, 1.11; 95\% CI, 0.91-1.34; $p=0.30$ ). However, the mortality rate was higher in the restrictive group compared with the liberal group (4.2\% vs. 2.6\%; HR, $1.64 ; 95 \% \mathrm{CI}, 1-2.67 ; p=0.045)$. Also in cardiac surgical patients, Carson et $\mathrm{al}^{31}$ found that the development of myocardial infarction or unscheduled revascularization at 30 days was higher in the restrictive group compared with the liberal group ( 25.5 vs. $10.9 \%$ of patients; $p=0.054$ ), with higher mortality in the restrictive group (13\%; $p=0.032)$.

\section{Blood Conservation Strategies in Cardiac and Aortic Surgery}

Given the deleterious effects of transfusion, there has been a drive toward reducing exposure to blood products in cardiac surgery. Although this is challenging in the surgical patient, techniques have emerged to reduce PRBC use while maintaining homeostasis. Various blood conservation strategies (BCS) have been developed to decrease perioperative complications, improve outcomes, and reduce health care costs.

Avgerinos et $\mathrm{al}^{34}$ implemented a BCS comprising aggressive intraoperative autologous donation and utilization of shorter CPB circuits. In their study, they compared 1,126 patients with this strategy with a control group of 3,758 patients. Their protocol not only enabled use of a lower prime volume, but showed a significant reduction in the overall use of blood products (49-29\%; $p=0.02$ ), postoperative respiratory failure (7-3\%; $p=0.03)$, pneumonia $(3.1-1 \% ; p=0.01)$, chest tube output (mean, $730-350 \mathrm{~mL} ; p=0.01$ ), reoperation for bleeding $(2.5-1.2 \% ; p=0.04)$, and length of stay (8.2-6.1 days; $p=0.05)$.

Ad et al $^{35}$ used a BCS involving expanded use of cell salvage blood in place of cardiotomy suction, acute normovolemic hemodilution, and retrograde autologous priming. Their protocol showed a reduction in the use of blood products from 54 to $25 \%$ ( $p=0.001$ ), as well as a lower incidence of postoperative renal failure $(4-2.6 \% ; p=0.04)$, reoperation for bleeding $(4-2 \% ; \quad p=0.004)$, and 30-day readmission (12-6\%; $p<0.001$ ), with no difference in operative mortality.

Although scarce, the majority of transfusion research within aortic surgery is focused on BCS. Yaffee et $\mathrm{al}^{4}$ studied the effects of BCS in high-risk aortic procedures. The minimization of intraoperative hemodilution, tolerance of perioperative anemia, and education of the multidisciplinary cardiac surgery team did not yield a difference in morbidity $(p=0.9)$ or mortality $(p=0.4)$. There was a $58 \%$ reduction in the number of PRBC units given in the blood conservation group. This resulted in a total cost saving of $\$ 10,135.50$ (\$349.50 per patient).

Smith et al, ${ }^{5}$ using a similar strategy, showed that $74 \%$ of patients did not require intraoperative PRBC transfusion, with a $35 \%$ decrease in the rate of complications in the group exposed to up to one unit compared with those receiving greater than two units. There was a lower rate of major complications (respiratory/renal failure, sepsis, mortality) in patients receiving up to one unit of PRBC compared with those with more than two units ( 0 vs. $38 \%, p<0.001)$.

Parenthetically, implementation of electronic decision tools has provided insight into transfusion practices, showing that physician decisions sometimes do not comply with guidelines and clinical evidence. Razavi et $\mathrm{al}^{36}$ used a clinical decision support tool within the electronic medical record that required a physician to give their rationale when ordering 
cross-matched blood for cardiothoracic surgery patients. They showed an association with fewer transfusions (50.3-40.8\%), lower infection rates (3.3-1.1\%), and reduced health care costs after its implementation.

\section{Blood Transfusion in Other Specialties}

The negative effects of liberal transfusion practices extend well beyond the field of cardiac surgery. However, the evidence in medical and noncardiac surgical areas is also controversial. Elmi et $\mathrm{al}^{37}$ used the American College of Surgeon National Surgical Quality Improvement Program database to investigate the effect of blood transfusion on patients undergoing gastric resection. They found that PRBC use was independently associated with an increase in 30-day mortality (RR, 3.1; 95\% CI, 1.9-5.0; $p<0.001$ ), significant morbidity (RR, $1.4 ; 95 \% \mathrm{CI}, 1.1-1.6$; $p<0.001$ ), respiratory failure (RR, 2.3; 95\% CI, 1.6-3.3; $p<0.001$ ), infections (RR, 1.4; 95\% Cl, 1.1-1.6; $p<0.001$ ), and length of stay (RR, 1.2; 95\% CI, 1.1-1.2; $p<0.001)$. They advocate for the implementation of blood management strategies to reduce the use of blood products after gastrectomy for gastric cancer. Martin et $\mathrm{al}^{38}$ found that perioperative blood transfusion in patients undergoing hepatectomy is independently associated with postoperative morbidity (OR, 4.18; 95\% CI, 2.18-8.02; $p=0.0001)$ and mortality (OR, 14.5; 95\% CI, 3.08-67.8; $p=0.001$ ).

The effect of blood transfusion also impacts the pediatric population. Stone et $\mathrm{al}^{39}$ found an association with increased mortality in pediatric trauma patients who received transfusion within 24 hours of admission. Demaret et al $^{40}$ studied the effect of blood transfusions in critically ill children. They showed an association between blood transfusion and the development of multiorgan dysfunction (OR, 3.85; 95\% CI, 2.38-6.24; $p<0.001)$, prolonged ventilation time $(14.1 \pm 32.6$ vs. $4.3 \pm 9.6$ days, $p<0.001)$ and increased pediatric ICU stay $(12.4 \pm 26.2$ vs. $4.9 \pm 10.2$ days, $p<0.001)$.

Conversely, Zheng et $\mathrm{al}^{41}$ in a systematic review evaluating adult ICU patients concluded that there is a lack of strong evidence to support the negative effect of PRBC. After adjusting for confounders, they did not show a transfusion-related increase in in-hospital mortality.

\section{Possible Solutions}

Overall, the evidence points preponderantly toward a more conservative transfusion policy in cardiac surgery. The complexity and bleeding potential of aortic surgery warrants a more individualized approach, incorporating an assessment of the potential for operative mortality, and bleeding. In those patients with a high bleeding risk, efforts can be made to permit yet minimize the amount of administered blood transfusion.

- Preoperatively: Investigate and treat anemia, for example, erythropoietin, iron

- Intraoperative factors: meticulous surgical hemostasis, shorter CPB circuits, point of care testing for coagulopathy; salvage procedures (e.g., autologous blood transfusion, cell saver), correction of coagulopathy (antifibrinolytics, fresh frozen plasma, platelets, cryoprecipitate, factor VII)

- Availability of traditional and recombinant agents (aminocaproic acid, tranexamic acid, factor VII, and topical hemostatic agents) is laudable. Cardiac surgeons worldwide still bemoan the loss of aprotinin, which produced remarkably dry surgical fields ${ }^{42}$

- Postoperative: Careful surveillance for bleeding, regular $\mathrm{Hg}$ and hematocrit monitoring, treatment of sepsis (and other complications)

In cases where transfusion is required, it is important to consider the nature of blood being transfused. Specifically, leukoreduced blood and blood that has been stored for less than 14 days have a better safety profile with regards to immediate postoperative and long-term complications. ${ }^{10}$

Furthermore, the development of a multidisciplinary transfusion team (with surgeons, anesthesiologists, intensivists, perfusionists, nurses, and blood bankers) may help to ensure judicious use of blood products. ${ }^{2,13}$

Although each case should be considered on an individual basis, the current guidelines serve as an adjunct for decisionmaking. Medical and asymptomatic noncardiac surgical patients may benefit from a more restrictive approach, with an $\mathrm{Hg}$ threshold of less than 6 to $7 \mathrm{~g} / \mathrm{dL}$. For cardiac surgical patients and those with acute coronary syndromes, we must recognize that a more liberal approach (Hg threshold 9-10 g/dL) is beneficial to ensure sufficient oxygen delivery. 2,13

\section{Conclusion}

Blood transfusion is undoubtedly a lifesaving procedure if used appropriately. Nevertheless, it is not without harm, and there is much controversy surrounding the effects of transfusion on surgical outcomes. Despite the paucity of studies investigating this practice specifically in aortic surgery, there is some evidence showing an association between transfusion and adverse outcomes warranting greater vigilance regarding the use of blood products. Since aortic surgery is a particularly high risk, we advocate a thorough evaluation of the patient that balances the consequences of bleeding and anemia with the putative decreased survival associated with blood products. Further research is required to better define the effect of transfusion on short- and long-term outcomes in aortic surgery patients.

Conflict of Interest

None.

Acknowledgments

None.

\section{References}

1 Goodnough LT. Transfusion medicine. In: Goldman L, Schafer AI, eds. Goldman's Cecil Medicine. 25th ed. Philadelphia, PA: Elsevier Saunders; 2015:1191-1198 
2 Ferraris VA, Ferraris SP, Saha SP, et al; Society of Thoracic Surgeons Blood Conservation Guideline Task Force; Society of Cardiovascular Anesthesiologists Special Task Force on Blood Transfusion. Perioperative blood transfusion and blood conservation in cardiac surgery: the Society of Thoracic Surgeons and The Society of Cardiovascular Anesthesiologists clinical practice guideline. Ann Thorac Surg 2007;83(5, Suppl):S27-S86

3 McQuilten ZK, Andrianopoulos N, Wood EM, et al. Transfusion practice varies widely in cardiac surgery: Results from a national registry. J Thorac Cardiovasc Surg 2014;147(05):1684-1690.e1

4 Yaffee DW, DeAnda A, Ngai JY, et al. Blood conservation strategies can be applied safely to high-risk complex aortic surgery. J Cardiothorac Vasc Anesth 2015;29(03):703-709

5 Smith D, Grossi EA, Balsam LB, et al. The Impact of a Blood Conservation Program in Complex Aortic Surgery. Aorta (Stamford) $2013 ; 1(04): 219-226$

6 Chu MW, Losenno KL, Moore K, Berta D, Hewitt J, Ralley F. Blood conservation strategies reduce the need for transfusions in ascending and aortic arch surgery. Perfusion 2013;28(04): 315-321

7 Miller RD. Patient blood management: transfusion therapy. In: Miller RD, ed. Miller's Anesthesia. 8th ed. Philadelphia, PA: Elsevier Saunders; 2015:1830-1867

8 Liu H, Yan H, Christian S, et al. Physiological derangement of trauma patient. In: Scher CS, ed. Anesthesia for Trauma. 1st ed. New York, NY: Springer; 2014:45-65

9 Bunn HF. Approach to the anemias. In: Goldman L, Schafer AI, eds. Goldman's Cecil Medicine. 25th ed. Philadelphia, PA: Elsevier Saunders; 2016:1059-1068

10 Koch CG, Li L, Sessler DI, et al. Duration of red-cell storage and complications after cardiac surgery. N Engl J Med 2008;358(12): 1229-1239

11 Argalious MY, Dalton JE, Mascha EJ, Cywinski JB, Clair DG. Association of red blood cell transfusion and postoperative outcomes after endovascular aortic repair. Semin Cardiothorac Vasc Anesth 2011;15(1-2):49-55

12 Nussmeier N, Sarwar M, Searles B, et al. Anesthesia for cardiac surgical procedures. In: Miller RD, ed. Miller's Anesthesia. 8th ed. Philadelphia, PA: Elsevier Saunders; 2015:2007-2095

13 Ferraris VA, Brown JR, Despotis GJ, et al; Society of Thoracic Surgeons Blood Conservation Guideline Task Force; Society of Cardiovascular Anesthesiologists Special Task Force on Blood Transfusion; International Consortium for Evidence Based Perfusion. 2011 update to the Society of Thoracic Surgeons and the Society of Cardiovascular Anesthesiologists blood conservation clinical practice guidelines. Ann Thorac Surg 2011;91(03): 944-982

14 Koch CG, Li L, Duncan AI, et al. Transfusion in coronary artery bypass grafting is associated with reduced long-term survival. Ann Thorac Surg 2006;81(05):1650-1657

15 Yu PJ, Cassiere HA, Dellis SL, et al. Dose-dependent effects of intraoperative low volume red blood cell transfusions on postoperative outcomes in cardiac surgery patients. J Cardiothorac Vasc Anesth 2014;28(06):1545-1549

16 Surgenor SD, DeFoe GR, Fillinger MP, et al. Intraoperative red blood cell transfusion during coronary artery bypass graft surgery increases the risk of postoperative low-output heart failure. Circulation 2006;114(1, Suppl):I43-I48

17 Koch CG, Li L, Duncan AI, et al. Morbidity and mortality risk associated with red blood cell and blood-component transfusion in isolated coronary artery bypass grafting. Crit Care Med 2006;34 (06):1608-1616

18 Paone G, Likosky DS, Brewer R, et al; Membership of the Michigan Society of Thoracic and Cardiovascular Surgeons. Transfusion of 1 and 2 units of red blood cells is associated with increased morbidity and mortality. Ann Thorac Surg 2014;97(01):87-93, discussion 93-94
19 Koster A, Zittermann A, Börgermann J, et al. Transfusion of 1 and 2 units of red blood cells does not increase mortality and organ failure in patients undergoing isolated coronary artery bypass grafting. Eur J Cardiothorac Surg 2016;49(03):931-936

20 Murphy GJ, Reeves BC, Rogers CA, Rizvi SI, Culliford L, Angelini GD. Increased mortality, postoperative morbidity, and cost after red blood cell transfusion in patients having cardiac surgery. Circulation 2007;116(22):2544-2552

21 Isil CT, Yazici P, Bakir I. Risk factors and outcome of increased red blood cell transfusion in cardiac surgical patients aged 65 years and older. Thorac Cardiovasc Surg 2015;63(01):39-44

22 Yun JJ, Helm RE, Kramer RS, et al; Northern New England Cardiovascular Disease Study Group. Limited blood transfusion does not impact survival in octogenarians undergoing cardiac operations. Ann Thorac Surg 2012;94(06):2038-2045

23 Carrascal Y, Maroto L, Rey J, et al. Impact of preoperative anemia on cardiac surgery in octogenarians. Interact Cardiovasc Thorac Surg 2010;10(02):249-255

24 Wu WC, Rathore SS, Wang Y, Radford MJ, Krumholz HM. Blood transfusion in elderly patients with acute myocardial infarction. N Engl J Med 2001;345(17):1230-1236

25 Dardashti A, Ederoth P, Algotsson L, Brondén B, Lührs C, Bjursten H. Blood transfusion after cardiac surgery: is it the patient or the transfusion that carries the risk? Acta Anaesthesiol Scand 2011; 55(08):952-961

26 Warwick R, Mediratta N, Chalmers J, et al. Is single-unit blood transfusion bad post-coronary artery bypass surgery? Interact Cardiovasc Thorac Surg 2013;16(06):765-771

27 Cambria RP, Clouse WD, Davison JK, Dunn PF, Corey M, Dorer D. Thoracoabdominal aneurysm repair: results with 337 operations performed over a 15-year interval. Ann Surg 2002; 236(04):471-479, discussion 479

28 Muñoz M, Ariza D, Gomez-Ramirez S, Hernandez P, García-Erce J, Leal-Noval S. Preoperative anemia in elective cardiac surgery: prevalence, risk factors, and influence on postoperative outcome. Transfus Altern Transfus Med 2010;11(02):47-56

29 Hogervorst EK, Rosseel PM, van de Watering LM, et al. Intraoperative anemia and single red blood cell transfusion during cardiac surgery: an assessment of postoperative outcome including patients refusing blood transfusion. J Cardiothorac Vasc Anesth 2016;30(02):363-372

30 Karkouti K, Wijeysundera DN, Yau TM, McCluskey SA, van Rensburg A, Beattie WS. The influence of baseline hemoglobin concentration on tolerance of anemia in cardiac surgery. Transfusion 2008;48(04):666-672

31 Carson JL, Stanworth SJ, Roubinian N, et al. Transfusion thresholds and other strategies for guiding allogeneic red blood cell transfusion. Cochrane Database Syst Rev 2016;10:CD002042

32 Carson JL, Brooks MM, Abbott JD, et al. Liberal versus restrictive transfusion thresholds for patients with symptomatic coronary artery disease. Am Heart J 2013;165(06):964-971.e1

33 Murphy GJ, Pike K, Rogers CA, et al; TITRe2 Investigators. Liberal or restrictive transfusion after cardiac surgery. N Engl J Med 2015; 372(11):997-1008

34 Avgerinos DV, DeBois W, Salemi A. Blood conservation strategies in cardiac surgery: more is better. Eur J Cardiothorac Surg 2014; 46(05):865-870

35 Ad N, Holmes SD, Patel J, et al. The impact of a multidisciplinary blood conservation protocol on patient outcomes and cost after cardiac surgery. J Thorac Cardiovasc Surg 2017;153(03):597-605.e1

36 Razavi SA, Carter AB, Puskas JD, Gregg SR, Aziz IF, Buchman TG. Reduced red blood cell transfusion in cardiothoracic surgery after implementation of a novel clinical decision support tool. J Am Coll Surg 2014;219(05):1028-1036

37 Elmi M, Mahar A, Kagedan D, et al. The impact of blood transfusion on perioperative outcomes following gastric cancer resection: an analysis of the American College of Surgeons National Surgical 
Quality Improvement Program database. Can J Surg 2016;59(05): 322-329

38 Martin AN, Kerwin MJ, Turrentine FE, et al. Blood transfusion is an independent predictor of morbidity and mortality after hepatectomy. J Surg Res 2016;206(01):106-112

39 Stone TJ, Riesenman PJ, Charles AG. Red blood cell transfusion within the first 24 hours of admission is associated with increased mortality in the pediatric trauma population: a retrospective cohort study. J Trauma Manag Outcomes 2008;2(01):9

40 Demaret P, Tucci M, Karam O, Trottier H, Ducruet T, Lacroix J. Clinical outcomes associated with RBC transfusions in critically ill children: a 1-year prospective study. Pediatr Crit Care Med 2015; 16(06):505-514

41 Zheng Y, Lu C, Wei S, Li Y, Long L, Yin P. Association of red blood cell transfusion and in-hospital mortality in patients admitted to the intensive care unit: a systematic review and meta-analysis. Crit Care 2014;18(06):515

42 DeAnda A Jr, Elefteriades JA, Hasaniya NW, Lattouf OM, Lazzara RR. Improving outcomes through the use of surgical sealants for anastomotic sealing during cardiovascular surgery. J Card Surg 2009;24(03):325-333
43 Jakobsen CJ, Ryhammer PK, Tang M, Andreasen JJ, Mortensen PE. Transfusion of blood during cardiac surgery is associated with higher long-term mortality in low-risk patients. Eur J Cardiothorac Surg 2012;42(01):114-120

44 Kleczynski P, Dziewierz A, Bagienski M, et al. Association between blood transfusions and 12-month mortality after transcatheter aortic valve implantation. Int Heart J 2017;58(01):50-55

45 Surgenor SD, Kramer RS, Olmstead EM, et al; Northern New England Cardiovascular Disease Study Group. The association of perioperative red blood cell transfusions and decreased longterm survival after cardiac surgery. Anesth Analg 2009;108(06): 1741-1746

46 Engoren MC, Habib RH, Zacharias A, Schwann TA, Riordan CJ, Durham SJ. Effect of blood transfusion on long-term survival after cardiac operation. Ann Thorac Surg 2002;74(04):1180-1186

47 Santos AA, Sousa AG, Thomé HO, Machado RL, Piotto RF. Impact on early and late mortality after blood transfusion in coronary artery bypass graft surgery. Rev Bras Cir Cardiovasc 2013;28(01):1-9

48 Engoren M, Schwann TA, Jewell E, et al. Is transfusion associated with graft occlusion after cardiac operations? Ann Thorac Surg 2015;99(02):502-508 